\title{
The first outline of Calvin's theology - the preface to the New Testament in the Olivétan Bible of 1535
}

\author{
W.H. Neuser \\ Department of Church History and History of Doctrine \\ Westfälische Wilhelms-Universität \\ Münster \\ GERMANY \\ E-mail: neuserw@uni-muenster.de
}

\section{Abstract}

The first outline of Calvin's theology - the preface to the New Testament in the Olivétan Bible of 1535

The prefaces which Calvin wrote for the Bible translation of Olivétan (1535) conform to the general custom during the Reformation to translate the Bible into the vernacular and to publish these translations simultaneously with interpretation aids. In the preface published in the Olivétan Bible and preceding the New Testament translation, Calvin wants to indicate to the reader (in this case the heathen) the correct way to approach the Bible.

Although no captions or headings are included, the preface is structured very precisely, thus also presenting Calvin's systematic kind of exposition.

In order to show the heathen the way to salvation, Calvin indicates a way via prehistory (Gen. 1-11; Rom. 1-2; Acts 14 and 17), the Ten Commandments (Decalogue) to the New Testament witness about Christ. The focus and goal of this path are the fulfilment of the law. Clearly the most noticeable result of the analysis of this preface is the "system of corresponding doctrines" found between creation and salvation. This specific approach of Calvin is a key to understanding his later theology.

In the second part of the preface Calvin explains the main Biblical concepts of "Testament", "Evangelium" and "Messiah". Regarding this his view corresponds to Luther's writing, "De captivitate Babylonica ..." (1520), and is perhaps dependent on it.

The third part of the preface contains admonitions to Christians who are persecuted to assure them of their salvation. Admonitions to kings, princes, rulers, bishops and pastors are also included. 


\section{Introduction}

When one attempts to analyse "Dieu le createur", the French preface to the New Testament in the Bible of Olivétan, there are two important questions.

\section{What do we know about the so-called Bible of Olivétan?}

In 1528 Pierre Robert Olivétan left France, after having joined the Reformation movement shortly before. In Neuchâtel he took over a ministry in 1533. During visits to the valleys of the Waldensians in Piemont, their congregations quite eagerly asked him for a complete French Bible - a wish which Olivétan complied to. The printing of his Bible translation had already been completed at the fourth of July 1535 while he stayed in Neuchâtel. It was the second complete Bible in the French language, after the publication of Faber Stapulensis' (Lefèvre d'Etaples) translation which was published in parts between 1523 and 1530 (the latter, however, being only a translation from the Latin).

When Calvin, a cousin of Olivétan, arrived in Basle in January 1535, he was asked to write some prefaces to be printed in Olivétan's Bible translation. The first of these prefaces, which was written in Latin, defends the fact that this Bible appeared without the usual Privilege of the King because "The Word of God needs no privilege of any king to be published". The preface which requires our attention as subject of our investigation, actually is a preface to the New Testament. The other French preface (preceding the Old Testament), presumably also from the hand of Calvin, is not part of this analysis.

It should be noticed that present-day publications of the Bible normally have only the text of the Bible, without any additional interpretation or explanations of the biblical text. In other words: today the text of the Bible and its interpretation usually are separated from each other and not published together. Many people often have the idea that the "Word of God" can stand on its own. We, however, forget that for example the Gospels of Matthew, Mark, Luke and John are divided into different pericopes for the purpose of interpretation and proclaiming the Gospel; or that the lists of the charismata in Romans 12 and 1 Corinthians 12 for the most part are gifts of interpretation of Scripture. Holy Scripture and its interpretation go together. The way in which the Reformers connected the Bible text with their commentaries illustrates that they had been aware of this unity. Of course, one could say that they did not have any choice, due to the fact that the earliest translations during the Reformation had to accommodate readers who did not know the Bible and had to detach themselves from unbiblical Roman doctrines. But in response to this objection one should mention the fact that the prefaces of Luther 
were included in the translated editions of single biblical books - not only during the beginning years of the Reformation but also later on. Also the Zurich Bible (the New Testament was published in 1524) and other translations in European languages at that stage included "Summaries", which were meant as a certain kind of aid to the reader. The text of the Bible and these reading aids were published together. The Aufklärung and the new kind of critical research of the Bible resulted in the end of these kind of Bible editions (biblical text published together with its interpretation). In 1811 the influential British and Foreign Bible Society decided to publish the Bible text alone and to translate it into as many languages as possible. Although editions which include explanations of the Bible text, together with the text itself (Bibelwerke), were still published, it became the exception. The interpretation was increasingly presented solely in scientific commentaries (Wootton, 1980:308; cf. Raeder, 1980). The common church people now only had the uncommented Bible at their disposal. Therefore the prefaces of Calvin which were included in Olivétan's Bible were no exception; actually it was in accordance with the order of the day.

\section{Why is the preface described as "the first outline of Calvin's theology"?}

The second question regarding "Dieu le createur" is about the way I describe the preface, namely as "the first outline of Calvin's theology" and hence a key to the theology of the Genevan Reformer. If we consider the past and current research on Calvin's Institutes, we come to the conclusion that the contents of the Institutes has been well investigated, and although there are some smaller questions left (especially those regarding some details), the train of thought is clear and the modifications to the later versions of the Institutes are easy to understand. However, Calvin's point of departure, his theological intention is still not clarified very satisfactorily. Why does he follow this specific line of thought in the Institutes and not any other? It would be incorrect to say this line of thought is the only biblical and therefore the conclusive one. As a matter of fact, it is not. The other Reformers applied different methods in their theological summaries. Besides, their various dogmatic systems did not correspond at all. It is well-known that Calvin wanted to give an introduction in understanding the Bible. But what is his angle of approach? Which are his points of departure? As long as we do not know the answers on these questions, his theology as a whole will stay rather unclear and many details will also be obscure. It is certainly not accidental that there is still no book with the title "The theology of Calvin" which presents more than only a table of contents of the Institutes. 
The aim of this analysis is to show one way of understanding Calvin's theology. By proposing to start at the very outset of his theological beginnings, the purpose is to find out which dogmatic intentions Calvin pursues. The steps which follow in his successive writings will then proceed either the same line or will be divergent - but his point of departure will always be the same. In any case, his way of thinking will be disclosed. One of the first Protestant publications of Calvin that we have, is his preface to the New Testament in the Olivétan Bible of 1535. On the whole, this script remained rather unnoticed in research studies.

Firstly I want to present the structure of this writing; then I would like to indicate the line of thought in this preface, with finally an interpretation of its theology.

\section{The structure}

Although the preface is structured in a very logical way, Calvin does not divide it into any parts or sections. Therefore it is helpful to consult the special reprint of the writing of 1543. It bears the title "How our Lord Jesus Christ is the end, the fulfilment of the Law and the sum total of all that one has to seek in the Holy Scripture". (Cf. Peter \& Gilmont, 1991:43/8, "Deux epistres". The author of the second letter is Viret.) When one applies the claim of the title to the text of the preface of 1535, it is apparent that it matches the text. The script of 1543 is - like the preface of 1535 - also divided into two parts. The first part ends with the statement that Christ is the end (or: fulfilment) of the law; the second contains the synopsis: an explanation of the cardinal terminology of the Bible.

Probably the title of the reprint of 1543 was not added later on in order to explain the contents. That can be proven by the line of thought. Although no evidence has yet been found that an earlier print with this title existed, there is some reason to believe that the origins of the title lay further back than 1543.1 (In this regard one should remember the fact that we have only one copy of the Catechism of Geneva of 1537 [Peter \& Gilmont, 1991:37/2]. If this copy had not been preserved, the Catechism would have been unknown to us.) The preface's title from 1535, "Letter [or 'Greeting'] to all who love Jesus Christ and his Gospel" is an address or a salutation and is no heading. It gives some information about the people addressed, but not about the contents. 
There is only one difference between the text of 1535 and that of 1543 . In the latter the short paragraph between the first and second part, explaining the translation work by Olivétan, was omitted. It would not have made sense to include this paragraph in the separate reprint. Instead we find some (new inserted) sentences on the origins and evolvement of the text of the New Testament. 2

At the end of the preface Calvin gives extensive admonitions to Christians, kings and bishops. (For the purpose of this article it is helpful to combine these admonitions in Part III.)

The composition of the preface is as follows:

Part I. How our Lord Jesus Christ is the end (and fulfilment) of the law [= 1543]:

1. From creation to the tower of Babel (Gen. 1-11)

2. Man who departed from God only knows God partially (Rom. 1-2; Acts 14 and 17)

3. The goodness and kindness of God towards Israel (Ex. 2-20)

4. Israel and the Gentiles are addicted to idolatry (Ex. 32, Rom. $1: 21 \mathrm{ff}$.)

5. The hope of recovery in the Old Testament

6. The fulfilment of the law by the coming Messiah

Part II. The sum total of all that one has to seek in the Holy Scripture [= 1543]:

1. The terms Testament and Gospel

2. The assurance that Jesus Christ is the promised Messiah

Part III. Admonitions:

1. Exhortations to all Christians:

True faith during persecutions

Jesus Christ our help

2. Admonition to kings, princes and (state) authorities

3. Admonition to bishops and pastors

2 Cf. CO 9,801 and footnote 2. Calvin is not the author of the new insertion, because twice the phrase "Seigneur lesus" are used twice, whereas Calvin always writes "Jesus Christ". 
Calvin presents a treatise which is structured very precisely. The first part spans the time from creation to the coming of Christ. The second part mentions and explains the principal New Testament terms. The third part consists of admonitions. This general characterisation does not, however, describe the peculiarity of the first two parts of the preface. They have to be analysed in detail.

\section{The line of thought ${ }^{3}$}

\subsection{Part I of the preface: How our Lord Jesus Christ is the end (and fulfilment) of the law (1543)}

Previous examinations or publications of the preface (cf. e.g. Calvin, 1909:177-204; Calvin, 1929; Calvin, 1963; Calvin, 1986; Calvin, 1994; Quack, 1975:94-112) neglected to add to the Calvin text all the Bible quotations by Calvin or to mention all the places in the Bible to which he refers. There are actually quite a number of quotations. Ganoczy, without publishing this text, notices on discussing it: "One has the impression that Calvin used no other sources than the Bible itself ..." (Ganoczy, 1988:96). A number of references have been added to the text (in footnotes, see the appendix to this article). The result of inserting the relevant Biblical texts is remarkable and very astonishing with regard to the first part, where the gentiles' knowledge of God is treated. Calvin namely uses almost exclusively Romans 1 and 2, as well as Acts 14 and 17 , i.e. the prominent sections where Paul discusses the knowledge of God given to the gentiles or respectively, where he preaches to the gentiles.

As is well-known, in that specific context the apostle Paul makes use of the conventional elements of his time, as practised by the gentile-mission by the Jewish. He takes for granted that all the gentiles acknowledge God as the Creator, as the Sustainer of the world, as the Judge and as the God of kindness, tolerance and patience. Finally, Calvin traces in these texts a knowledge of the natural law which is implanted in man's conscience (Rom. 2:15). In these three speeches Paul calls on the gentiles to repent. In addition to these Bible texts Calvin quotes verses of Genesis 1 to 11 , i.e. the beginning of the general history of man, and also from some of the Psalms treating God's tracks in nature, e.g. Psalm 19 and 98 etc. These psalms praise God for his magnificence in nature.

3 For the purpose of reference I enclosed as appendix an English translation with sections and lines numbered (referred to as "appendix"). The enclosed English translation is derived from Calvin (1958) and Calvin (1963); the latter is more exact. 
When Calvin reconstructs the way which God pursues in regard to the gentiles, on the basis of the above-mentioned Bible texts, he draws a picture which is quite different from the history of salvation (Heilsgeschichte) in the Old Testament. To clarify this point, the way in which Calvin excerpts information from Paul's speeches about the gentiles (in Romans and Acts, as well as from the Old Testament) will be examined.

\subsubsection{From creation to the tower of Babel (Genesis 1-11)}

\subsubsection{Genesis 1-3 (see appendix, section 1)}

At the outset Calvin mentions the creation of man as image and likeness of God. Then he points to the loss of this "singular excellence" by human pride. One could say Calvin reformulates the narrative of Genesis 1 to 3. Aspects that are, however, not mentioned include the following: the creation in seven days, the names of Adam and Eve, the term "fall of Adam" or "fall of man", the narration of the serpent as well as the expulsion from the paradise. Of the well-known terms and phrases from the history of creation, only "creation" and the phrase "image and likeness of God" remain. With regard to creation, Calvin refers to Genesis 1:1, Romans 1:20 and Acts 14:15: "You should turn from these vain things to a living God who made the heaven and the earth and sea and all that is in them". Concerning God's image, Calvin relates Genesis 1:26 to Acts 17:28 where Paul proclaims "we are of his kind". Then Calvin describes "image and likeness" as follows: "in humility man should bow himself lowly before the majesty of God" by "magnifying God with thanksgiving" and as praise towards God. In this regard, Calvin follows Romans 1:21, "for although they knew God they did not honour him as God or give thanks to him". The fall of man is thus seen as pride and arrogance towards God. Calvin describes the fall with the words "But the wretched man, wanting to be somebody in himself, began without restraint to forget and to misunderstand from whence the good (Acts 14:17) came to him".

According to this preface the fall of man in paradise was not a singular event, but this fall continually takes place. The fall is understood as an ongoing procedure. Using the past tense in his description Calvin means that all people already live in arrogance and pride towards God; no one is without guilt. It is no coincidence that Calvin speaks of man and not of Adam. Therefore it would be appropriate not to call this process "the fall" of man, but rather the loss of God's image and likeness as a result of man's own guilt. In a certain section of the preface Calvin even tries to connect Paul and Genesis 1-3 by saying "man went down in ruin". 
But similar to Paul's reasoning in Romans and Acts, Calvin tries to maintain the connection with the Old Testament. This is illustrated when he speaks about "the Lord of power". According to Romans 1:20 the gentiles recognise God's power from his works of creation (although "Lord of power" is also the translation of the Hebrew name of God, "Zebaoth").

\subsubsection{Genesis 4 to 11 (see appendix, section 2)}

In this part of Genesis the name Noah, the Great Flood, as well as of the rainbow and the Tower of Babel are not mentioned. Calvin only uses general biblical statements: God's grief to have created man (Gen. 6:6) or the "cursed seed" (Gen. 3:17) which produces "wickedness" and "evil" (Gen. 6:5). Again Calvin refers to the biblical pre-history. These terms though correspond with Romans 1 and 2, as well as with Acts 14 and 17.

However, from there on the link to the Old Testament, with the exception of some Psalms, is cut off totally. Calvin develops a "natural theology" which is timeless and therefore is also applicable to the present day. This "natural theology" requires our full attention.

\subsubsection{Man who departed from God is able to know God partially (see appendix, section 3)}

Man's loss of the divine image and likeness belonged to the plan of God or it led to a new intention of God. Calvin expresses it this way: The ruin of man happened

... to the end that man be confounded in his pride and to constrain him to learn what he did not want to hear voluntarily, namely that he was by himself nothing but vanity, and would never have been anything else except with the assistance of the Lord of power.

The above means that the fall in ruin is simultaneously for man the beginning of a learning process. His loss is the beginning of a new divine plan; man has something to "understand" or to "learn". The contents of his learning is: man is of no significance at all and help comes from God only. Or: man is (totally) dependent on God who alone has majesty and power.

The plan of God contains, however, more. Calvin's reasoning develops from Romans 1:20 to Romans 2:4 by stating: "Nevertheless, the Lord of mercy, who not only loves but is himself love and charity, being prepared in his infinite goodness, to love man who deserved no love, did not entirely expel, consume and ruin men ..., but he sustained and supported them in kindness and patience". The attributes of God, namely "kindness, tolerance and patience" are taken from Romans 2:4a ("Or do you 
presume upon the riches of his kindness, tolerance and patience?"). But the additional attributes which Calvin specifies, "mercy", "love" and "charity", are not mentioned by Paul in this terms and context. We have to notice that Calvin uses the text of the Bible, i.e. Paul's statements, to the extent of the measure of the knowledge the gentiles have.

The process of learning continues; in this respect Calvin follows Paul again: God gives time and opportunity to the gentiles to return to him. Paul says in Acts 17:30: "God overlooked the time of ignorance, but now he commands all men everywhere to repent". Calvin says: God disguised himself and kept silent. Certainly Calvin has Romans 1:20 as well as Acts 14:16 in his mind, where Paul says: "In past generations he allowed all nations to walk in their own ways". God left all nations to follow their desires and the yearnings of their lust (cf. Rom. 1:24). He, however, did not leave them without the (natural) law (Rom. 2:12 ff.). He also gave them indications (advertissements) to seek him, to reach out for him and to find him. (The last part of the sentence is a quotation from Acts 17:27.)

Calvin deduces these indications (which are in nature to know God) from Acts 14:17 ("He did not leave himself without witness") and from Romans $1: 19$ ff. ("For what can be known about God is plain to them, because God has shown it to them. Ever since the creation of the world his invisible nature, namely his eternal power and deity, has been clearly perceived in the things that have been made".) Calvin explains these indications in nature carefully. They are wordless, "ensigns and emblems"; they are "escutcheons of clear intelligence". That means one can look at them and they speak to the observer. Then he explains the way by which the gentiles will come to know God after initially having turned away from him. Because God's power and deity is recognisable from the works of creation, everybody should know the sovereign Lord whose magnificence is engraved in all parts of the world, in heaven and on earth. These "signs" in creation show his glory, power, kindness, wisdom and eternity. Calvin then subsequently presents in detail the praise of God in the animated and unanimated nature (birds, beasts, elements, mountains, rivers, fountains, herbs, flowers). Yes, man also does not need to go far to seek him, because every one can find him in himself (Acts 17:27); his power is in us (Acts 17:28: "In him we live and move and are"). At this point the section on natural knowledge about God ends in the preface.

\subsubsection{The goodness and kindness of God towards Israel (see appendix, section 4)}

In this context Calvin is not interested in the salvation history (Heilsgeschichte) of Israel. As has already been indicated he touches the 
biblical pre-history in Genesis 1 to 11 , but mentions only facts which are of importance for the gentiles. In this section he jumps to a later part of the history. Abraham, Isaac and Jacob, however, remain unmentioned. Calvin narrates the events from the liberation in Egypt until the establishing of the Covenant and the handing over of the Ten Commandments at Sinai. In his line of argumentation Paul needs to outline the implication of the Covenant and the Law to explain the mediator of the New Covenant, Jesus Christ.

\subsubsection{Israel and the gentiles are addicted to idolatry (see appendix, section 5)}

Calvin inserts a section to clarify that the gentiles did not notice the works of creation while they were blind, and that the old covenant and Ten Commandments did not suffice to save Israel. The accusation against Israel is short, whereas the accusation against the gentiles is elaborate. This corresponds with Calvin's aim to explain the learning process in more detail to the gentiles. In a previous part of the preface he treated Romans 1:19 and 20 (knowledge about God from the works of creation). In this section he proceeds to Romans 1:21 ff. indicating that the gentiles' knowledge about God changed into idolatry. "Claiming to be wise they became fools" (Rom. 1:22). With this insight Calvin closes his description of the period of the Old Testament, with regard to the gentiles as well as to the Jews. Calvin makes the transit to Jesus Christ by saying: "Wherefore if God were to approach his people, whether Jew or Gentile, a new covenant was needed, ... it was necessary to have a mediator, ... it was our Lord and Saviour Jesus Christ".

\subsubsection{The hope of recovery in the Old Testament (see appendix, section 6)}

In this section Calvin delivers the biblical evidence of the announcement of Jesus Christ in the Old Testament. But again he is not interested in the traditional history of salvation (Heilsgeschichte) which proves that Jesus Christ is prophesied in the Old Testament. Rather he wants to show the universality and great variety of the expectations and anticipations of the Messiah in the Old Testament: Adam, after turning away from God, is consoled, because the descendants of the woman will crush the head of the serpent (Gen. 3:15); through the offspring of Abraham "all people on earth" will be blessed (Gen. 12:3); the same is applied to the promise to Isaac (Gen. 26:24); Jacob prophesies the hope of all "nations" (Gen. 49:10). The contents of this prophecy ("The sceptre will not depart from Judah ... until the ruler comes") leads Calvin to add the fulfilment: 
Which was verified at the time (!) when Jesus Christ came to the world. For the Romans, after having divested the Jews of all government and control, had (about thirty years before) appointed Herod as king over them; he was a stranger, his father Antipater being an Idumean, and his mother an Arabian. It happened several times before that the Jews had been without kings; but they had never been, as they were at this time [of Herod], without counsellors, governors or magistrates.

Not Jesus Christ, but in general the time of his coming is object of the prophecy of Jacob.4 Calvin proceeds and continues to Daniel 9:24: "Another description of it (i.e. the date of Christ's coming) is given in Daniel, in the calculation of the seventy weeks". But Calvin does not explain the calculation itself. Later, in his commentary on this text in the book Daniel (1561), he comprehends the seventy weeks of the restitution of the nation and the holy city as seventy years and relates this period to the time from the mandate at the end of the exile until the baptism of Jesus; although he calls this explanation not conclusive (CO 41,170 and 176). All in all, no less than thirteen Old Testament references about the coming of the Messiah of all nations are mentioned in this part. The exposition ends with the enumeration of the benefits of the law, which are portrayals and shadows of the much greater loving-kindness of Christ.

\subsubsection{The fulfilment of the law by the coming Messiah (see appendix, section 7 )}

To conclude the complete line of thought: the New Testament calls the law the guardian which leads to Christ (Gal. 3:24); Christ is the end and fulfilment of the law (Rom. 10:4), He is the Redeemer of those who were under the law (Gal. 4:4). This last comment with its christological focus refers especially to the gentiles too. They were led from the natural law through the Jewish law to Christ, who is the fulfilment of the law. It should, however, be remembered that although the christological

4 In his commentary on Genesis (1554) Calvin explains Genesis 49:10 to some extent differently, which emphasises the fact that there is still a reference to Herod: "Christians are commonly wont to connect perpetual government with the tribe of Judah, in the following manner. When the people returned from exile, they say, that, in the place of the royal sceptre, was the government which lasted to the time of the Maccabees. That afterwards, a third mode of government succeeded, because the chief power of judging rested with the Seventy, who, it appears by history, were chosen out of the legal race. Now, so far was this authority of the royal race from having fallen into decay, that Herod, having been cited before it, with difficulty escaped capital punishment, because he contumaciously withdrew from it" (CO 23,600, English translation). In the explanation following though, Calvin drops the historical continuity of the kingdom. 
dimension is implied, Calvin is still speaking about the Old Testament. In this section he presents a view on the New Testament, on the coming of the "great Messiah". The themes he uses to illustrate this are figuration and shadow (i.e. "the written law containing numerous ceremonies, purifications and sacrifices") as well as "embodiment" "of the blessings to come with Christ". He again mentions, like he did previously, the name of Christ. According to him the Old Testament is focused directly on Christ and the New Testament.

\subsection{Part II of the preface: The sum total of all that one has to seek in the Holy Scripture}

In the second part Calvin's line of thought is quite transparent: From the Old Testament path of salvation as well as according to Paul, Calvin proceeds to the central terminology, namely testament, gospel and Jesus Christ, "the true son of God".

\subsubsection{The terms testament and gospel (see appendix, section 8)}

With the term testament Calvin deals with the concept of the old and new covenant. Christ is the mediator of the new covenant; the old one was weak and uncompleted. Concerning gospel, Calvin introduces the thoughts of the Epistle to the Hebrews: gospel means the "good and joyful news". Calvin also refers to other New Testament main concepts: redemption, peace, righteousness, sanctification, salvation, life. He also declares that the death of Christ as well as his resurrection and his ascension were accomplished for us.

\subsubsection{The sureness that Jesus Christ is the promised Messiah (see appendix, section 9)}

Calvin refers to many witnesses from the New Testament. In the meantime the meaning and accomplishment of Christ's life and death are mentioned again. Calvin's intention is to stress that nobody is in a position to contradict the reality of Christ's accomplishment without resisting and rebelling against God's power. Calvin therefore knows very well that there is a gap between the old and the new covenant that has to be crossed. From the proclamation by Christ and from the soteriological contents he wants to prove it as irrefutable that Jesus Christ is the promised Messiah.

\subsection{Part III of the preface: Admonitions}

In this section exhortations to Christians, male and female follow; then to kings and magistrates, and finally to bishops and the rest of the clergy. 
- Exhortations to all Christians (see appendix, section 10)

The exhortations to the Christians are very detailed and extensive. They are given in the personal form of "we" (the first person). The trustworthiness of the Holy Scripture and the certainty of our salvation remain in the foreground.

- Certain faith during persecutions (see appendix, section 11).

- Jesus Christ, our help (see appendix, section 12).

- Admonition to kings, princes and (state) authorities (see appendix, section 13).

- Admonition to bishops and pastors (see appendix, section 14).

The line of thought in its whole is plain. Part I deals with the Old and Part II with the New Testament; Part III gives the practical results from the first two parts - admonitions in the form of a sermon. The topic, the first outline of Calvin's theology, consequently concentrates on Part I and II. Of these two parts, Part II, however, gives the expected summary of the New Testament from a Reformed point of view. Part I does not include the history of Israel though, but that of the gentiles. How is this possible? This issue will be discussed in the next section of this article.

\section{Theology}

After the structure and the line of thought have been examined, an estimation of the theological contents of the preface has to be made. Actually, quite a few surprises are to be found.

\subsection{Part I of the preface}

\subsubsection{The process of salvation regarding the gentiles}

It is apparent that Calvin does not want to draw a sketch of the biblical history of salvation (Heilsgeschichte). For his description of the history of man, Calvin certainly uses Romans 1 as well as Acts 14 and 17 as sources. As Stauffer indicates (1978), 5 Calvin later on also favours these verses (that could lead to a natural knowledge of God) in his sermons. In this context Ganoczy (1988:96) uses the concept "history of salvation". But Calvin does not formulate a second type of Heilsgeschichte in a Pauline way. Similar to what Paul does in his speeches, Calvin describes the path of salvation or the process of salvation, especially for the gentiles. He

5 Cf. particularly Chapter one (La revelation generale), where Stauffer (1978) gives much evidence. He does not see the connection though. 
explains this path or this process to his readers, that is, he wants to lead them to this understanding. Like Paul, Calvin delivers a missionary sermon directed to the gentiles. Simultaneously he describes this path as close as possible to the message of the Old Testament, just like Romans 1 and 2, as well as Acts 14 and 17.

\subsubsection{The proclamation of salvation}

That the preface has got a sermon-like character is apparent from the way Calvin writes: continually he turns from salvation to judgement, from divine love to human failure. This continuous interchange in the first part of the preface, with God on the one side and man on the other, will prove this observation.

The Creator endowed man with unique features, he created man to his own image and likeness.

Man should have glorified and praised God with gratefulness.

From God originates everything good,

but man was ungrateful, he felt in ruin and his splendour was taken away from him.

God had given man his own image and gifts of grace,

they were taken away from the fallen man.

God had made man with the intention to take a delight in him, like a father would have taken delight in his dear child;

but from that time God began to hate man.

Nevertheless the Lord of mercy, love and charity loved man,

although man didn't deserve his love.

God endured man in kindness and patience, giving him time and opportunity to return to him;

man should have become obedient again.

God disguised himself and kept silent, yet he gave man enough indications to seek him, to feel him and to find him;

man should recognise God and honour God.

God engraved the glory of his power in the work of creation,

he wanted to direct man to seek him.

In nature the birds praise God by singing, the nature elements tremble at his presence, etc.;

man does not need to seek God far away; everyone is able to find God in him- (or her-)self. 


\subsubsection{The path of salvation - shown to the gentiles}

The fact that the preface has a sermon-like character does not rule out its systematical structure and features - like in the case of a catechism. The specific character of the preface has to lead in effect to a conclusive process of cognition which is compelling. On this point and with regard to this matter Calvin follows the tendency of the apostle Paul in his addresses to the gentiles by trying to persuade them. In the same way the reader of the preface can not avoid its systematical flow. With almost logical consequences he will be led to Jesus Christ. Paul also tried to confront his readers and hearers with strict facts. In Athens the listeners were leaving him at the moment when he started to mention the resurrection of Christ. It belongs to the character of natural theology that it pretends to be convincing to everybody. In a similar way also Calvin is anxious to present the Holy Scripture and the message of Christ in Scripture as to be clear and undoubtfully testified.

\subsubsection{Theology of nature and theology of revelation}

Calvin develops a theology of revelation from a natural theology; from the original knowledge of God he unfolds the knowledge of Christ. However, according to this, man has no competence to know God and also no freedom of will. Therefore man can in no way contribute to his own salvation, since original knowledge of God is a gift engraved by the Creator; it is granted, one can not claim it. That means, first of all, that man has a responsibility not to loose this gift. Secondly, this natural knowledge does not presuppose a permanent status of man. Calvin mentions the term "status", but what is precisely meant, is the original state, which man looses immediately. Calvin asks: "Now, what would have enabled man to remain in the state, in which he was created?" The answer to that question implies to be humble and to bow lowly before God's majesty (appendix: $23,13 \mathrm{ff}$.). The ability mentioned by Calvin, actually does not exist. The result is rather that "all have been blind to the light (Rom. 1:21), deaf to admonitions, and hardened against the commandments" (appendix: 26,29 ff.). The natural knowledge of God which is engraved in the heart of man remains a gift of God, which man always looses. This kind of natural theology is quite different from the doctrines of Protestant scholasticism or the scholastic teaching of the Middle Ages which are also known as "natural theology". Actually it is no "natural theology" but a "theology of creation".

Consequently, the fall of man, described by Paul in Romans 1 and by Calvin in this preface, is understood as a permanent process, a process which extends from the possibility of knowledge about God to the complete distortion of the true image of God. Man always falls in idolatry (Rom. 1:22). The likeness of God is "effaced from man" (appendix: 24,7). When 
Paul and Calvin speak about man and not about Adam, consequently no singular fall is implied but a permanent and continuous losing of the likeness of God.

The development from a theology of creation to a theology of the New Testament proceeds along two tracks. Firstly, all men continue to know in their consciences the natural law, and God meets man in kindness, tolerance and patience (Rom 2:4). Man, however, continuously falls into sin. Secondly, Christ is the end and fulfilment of the law and therefore our Redeemer.

\subsubsection{Calvin's system of corresponding doctrines}

When Calvin uses the natural knowledge (which is engraved into man since his creation) as foundation as well as a point of departure for his line of thought, he develops a dogmatic system, which until now has not been noticed in the research on Calvin. It is a system of corresponding doctrines. This system emerged in the preface of the Olivétan Bible and was executed in the Institutes of 1536. Calvin notices a correspondence between the state of creation, the state after the fall and the state of grace in Christ. Some examples can make this clear.

\subsubsection{First example: The nature praises God and Christ}

The attentive reader is already puzzled when he reads two statements of Calvin which refer to the behaviour of the creatures.

The works of creation: Birds, beasts, elements, mountains, rivers and fountains, herbs and flowers point to God and glorify him (appendix: $25,20 \mathrm{ff}$.):

Christ: He demonstrates his power and gains honour; He stops the wind and pacifies the water; the fish brings the drachmas, the rocks crumble, the sun darkens, the tombs open etc. (appendix: 32,23 ff.).

According to the psalms, nature praises God, but nature serves Jesus Christ too. Both statements are corresponding and form a bridge between the doctrine of creation and the message of Christ.

\subsubsection{Second example: Community with God and with Christ}

Works of creation: God is near to men; "in him we live and move and are" (Acts 17:28) (appendix: 25,24; 26,1).

Christ: Christians have Christ in their presence, they are blessed by him; Christ lives in us (Gal. 2:20), we are seated in heavenly places (appendix: $35,1 \mathrm{ff} . ; 37,10 \mathrm{ff}$.). 


\subsubsection{Third example: The nature of God}

Works of creation: They testify about God's power, kindness, wisdom and eternity (appendix: 25,11 ff.).

Fallen man: $\mathrm{He}$ is blind towards God's glory and magnificence, towards the power of the divine law, God's good gifts and beneficence (appendix: 26,23 ff.).

After the fall: God remains the God of strength, mercy, love, charity, kindness and patience (appendix: 24,3; 24,22 ff.).

Christ: On him alone depends our redemption, peace, justification, sanctification, salvation, life (appendix: 30,20 ff.).

However, Calvin does not define the nature of Christ parallel to the original knowledge of God. This step will be taken in his Institutes of 1536.

The systematic arrangement of corresponding doctrines begins in this preface. It shows the principle that the manifestation of God in creation and in Christ has the same structure and the same contents. In the Institutes Calvin will elaborate on this system in its subsequent consequences. In order to teach the system of corresponding doctrines Calvin pays the price, as mentioned, to enlarge the attributes of God the Creator much more than Paul does in Romans 1 and 2.

\subsubsection{The origin of Calvin's "natural" theology}

The theme of natural theology is as old as the Bible and its interpreters. Calvin may have received the suggestion to deal with this doctrine from many theologians. But the peculiarity of Calvin's natural theology is the fact that it is founded on the Pauline statements about the gentiles. This points to the influence of Heinrich Bullinger from Zurich. Already in 1533, in discussing Romans, chapters 1 and 2 in his commentary on this Pauline letter, Bullinger had referred to the Pauline sermons in Acts 14 and 17. Calvin incorporated this indication in his own thinking and extended it to an angle of approach in his own theology. Studying the Bible intensively he applied these passages from the Bible to describe the path of salvation which the gentiles have to follow. Like the small tiles in a mosaic Calvin put the verses of Paul together. In the same way as Bullinger, Calvin added references to the Nature Psalms as well as to some texts from Genesis 1 to 11. But at the end the dependence on Bullinger can be proven only after the Institutes of 1536 have been studied. In the Institutes Calvin adopts Bullinger's view of God and even his formulation, as well as its consequences for the Christology; the formulations correspond directly with each other. Again it shows his system of corresponding doctrines. 


\subsubsection{The preface on Jews and gentiles}

In Olivétan's Bible we find another French preface: "To our relatives and associates, the people of the Sinai Covenant" (cf. V.F.C., 1970; Locher, 1967:187-193). For me it is beyond all doubt that both prefaces, the one to the gentiles and the one to the Jews, were written by Calvin. That means that Calvin addresses the gentiles as well as the Jews in the prefaces. This perhaps could be an explanation for Calvin's noticeable outline of the gentiles' path of salvation as indicated in the preface to the New Testament. The Jews' path of salvation is given in the preface to the Old Testament.

The chief result of our analysis is the hypothesis that Calvin will proceed in elaborating this theological outline: in the Institutes of 1536 he will commence with the path of salvation or the process of salvation directed to the gentiles, namely the natural knowledge of God given to all mankind. On this foundation he will build up the complete Christian teaching, connected with a corresponding system of doctrines. Therefore this preface from 1535 fulfils a key position to comprehend the theology of the young Calvin.

\subsection{Part II of the preface}

Calvin enumerates the cardinal terminology (summe) which are necessary to understand the Bible. 6 They are the following terms: "testament", "Christ" "Messiah", "knowledge of God" in order to receive salvation or "ignorance of God", the "gospel (evangelium) which declares Christ", "wisdom".

\subsubsection{Testament}

Calvin's explanation of the term "testament" is quite striking, because it is based on Luther's script "De captivitate Babylonica ..." (1520; see Luther, 1966). ${ }^{7}$ In this script Luther interprets 1 Corinthians 11:25 ("this cup is the new testament") not first of all as "covenant", but as a reference to

6 Ganoczy (1988:96) is of opinion that the typical form of addressing the reader in the preface is an indication of its "doxological" character. But the preface is a dogmatic writing.

7 Saxer (cf. Calvin, 1994:30) also judges that Calvin did not get his idea of using the term covenant from Bullinger ("De testamento seu foedere Dei unico et aeterno", 1534). Possibly Budaeus was of decisive importance for Calvin. "But we want to point again to Luther's 'De captivitate Babylonica'”. It can be proven that this writing was well-known to Calvin when he wrote down the Institutes" (see Saxer's annotations in Calvin, 1994:30). Also cf. in this regard Saxer's reference (in his footnote 15) to Ganoczy. 
the "will" of someone which is deceased (see Hebr. 9:16) as well as a reference to "promise" and "heritage" (Rom. 4:13 ff.; Gal. 3:15-17). 8 In this way Luther connects the words by which the Lord's Supper was instituted with the "theology of the Word", which played an important role at the beginning of the Reformation. For Luther the terms testamentum, pactum, foedus and promissio were used in an equal way. Calvin follows Luther on both points. He also adds the term evangelium to this collection of significant terms. Luther also used the term evangelium on a certain important place, namely when he is dealing with the deed-and offer-character of the Mass. ${ }^{9}$ Probably this writing of Luther was the most effective of his writings; it influenced the breakthrough of the Reformation in a remarkable way. Also Zwingli, writing down his eighteenth Thesis in 1523, cites Luther when he treats the terms testamentum, pactum and foedus as equivalents; he as well uses Luther's explanation that the gospel is testament, inheritance and heritage (Neuser, 1977:26 ff.).

\subsubsection{Gospel (evangelium)}

Calvin's line of thought reaches its climax and its destination with his exposition of the term evangelium. "Without the gospel everything is useless and vain; without the gospel, we are not Christians; without the gospel all wealth is poverty ..." (appendix: 33,10 ff.) Calvin underlines the preaching character of the evangelium. It is "the Word of life", it is

8 In his book "De captivitate Babylonica" (1520) Luther describes the "third captivity" as the doctrine that the mass is a good work and sacrifice (WA 6,512). Luther writes: "The mass is the will (testament) of Christ which he bequeathed before his death, in order that it is delivered to the faithful" (WA 6,513).

If we ask what is this testament, then we will also get the answer to the question, what is the mass, what is its use and fruit (effect). [...] Without doubt the testament is the promise of the dying Lord where he specifies his heirs and publishes his heritage. [...] Paul explains this in detail - Rom. 4:3; Ga. 3:15-17; Hebr. 9:15-17. We recognise this clearly from the words of Christ (1 Cor. 11:24 ff.). Christ testifies about his death by saying 'This is my body given to you', 'This is my blood, which is poured out'. He names and marks the heritage by saying 'for the forgiveness of sins' (Matth. 26:28). He indicates the heirs when he says 'poured out for you and for many' ( 1 Cor. 11: 24, Matth. 26:28), that is, who accept it and believe in the promise of the testator. The faith namely turns one to be an heir.

From the beginning of the world this testament of Christ is inherent given in all the promises of God; all the old promises are confirmed in every new promise in Christ in future; that ratifies them and from that they are dependent. Therefore the terms pactum, foedus, testamentum of the Lord are common in the Scripture (WA 6,514).

9 Nisi enim Missam obtinuerimus esse promissionem Christi, seu testamentum, ut verba dare sonant, totum Evangelium et universum solatium amittimus (WA 6,523). At missa est pars Evangelii, immo summa et compendium Evangelii. Quid est enim universum Evangelium, quam bonum nuntium remissionis peccatorum? (WA 6,525). 
"releasing [of the faithful] from sins", it must be "heard" (appendix: 33,18 ff.) "O Christians, ..., hear this and learn" (appendix: 33,26). Calvin ends by emphasising the grace of the preaching which leads to faith. This is the big discovery of the Reformation.

\subsubsection{Polemic}

Ganoczy (1988:96) thinks this French preface is, as contrasted to the Latin preface, "without any critical or polemical allusions". But this is not quite correct. The reference to Romans 1:23 ("they exchanged the glory of the immortal God for images") when he mentions idolatry (appendix: $27,10 \mathrm{ff}$.) is only too straightforward. Or: without the gospel "we cannot tell good from evil ... the commandments of God from the ordinances of men" (appendix: 33,8 ff.). Human ordinances mean the ordinances of the Pope. Calvin also remarks on the persecution of the Protestants in France: their "injuries, curses, disgrace", privations of worldly honour, "banishment, proscriptions, privation from goods and riches", "afflictions, prisons, tortures, torments" (appendix: 34,19-31). The critical tone can not be overlooked. Finally Calvin admonishes the bishops "that it is not prohibited and forbidden to any Christian to be free to read, discuss and interpret this holy gospel in his own language" (appendix: 38,4 ff.).

\subsubsection{The addressees}

According to his missionary concern Calvin finally speaks to all people: "male and female, small and great, servant or lord, master or disciple, clergy or layman, Hebrew or Greek, French or Latin speaking" (appendix: 32,26-28). Then he draws a smaller circle: "Christians, male and female". Finally he specifies three special groups of addressees: "Those who have their affections fixed upon this world" - they should pursue eternal life. Secondly, "those who give themselves to the mechanical arts", and thirdly "those who aspire to a reputation of greatest excellence - they should strive "in the study of this divine wisdom" (appendix: 34,3 ff.). Calvin certainly mentions the addressees for pastoral reasons. But it seems as if the manual workers ("those who apply themselves to any mechanical arts") are mentioned in order to refer not only to the last group ("those who wish to be reputed the most wise"). Apparently the last group are the humanists. They are his special addressees. The call to study the heavenly wisdom corresponds with Calvin's systematical concerns and with his own biography. The greetings at the beginning, "To all those who love Jesus Christ and his evangelium", could refer to a specific group of Meaux, a movement which is known under the designation evangélisme (see Shimura, 1994:240 ff.). The emphasis of the reference to "Jesus Christ" could indicate a proof for this. 


\section{Conclusion}

Calvin has taught the path of recognition or the process of salvation, which was presented in this article, in all the editions of the Institutes. In the edition of 1536 he presents this system more briefly than in the preface. Therefore the French preface has to be examined very carefully. This preface offers a significant approach to his theology, because it is the first outline of his theology.10 Consequently this preface should receive a central position in the research of Calvin's theology.

\section{Bibliography}

\section{APPENDIX}

see footnote 3

CALVIN, J. 1863-1900 [1532-1564]. (In Ioannis Calvini Opera Quae Supersunt Omnia, Vol. I-LIX [= CO 1-59]. Ediderunt G[W]. Baum, E. Cunitz \& E. Reuss, Vol. I-LIX, in Corpus Reformatorum, Vol. XXIX-LXXXVII. Brunsvigae/ Berolini : Schwetschke et filium.)

CALVIN, J. 1909. CEuvres choisies de Jean Calvin. Genève : Compagni des Pasteurs de Genève.

CALVIN, J. 1929 [1535]. Épistre a tous amateurs de Jésus Christ. (In Pannier, J., éditeur, Publications de la Société Calviniste de France, No. 2. Paris : Fischbacher.)

CALVIN, J. 1958. Preface to Olivétan's New Testament. (In Calvin, J. Commentaries, Vol. 23. Newly translated and edited by J. Haroutunian, in colloboration with L.P. Smith. London : SCM Press. p. 58-73.)

CALVIN, J. 1963. Christ, the End of the Law. Translated from the French. Evangelical Magazine, 31:12-23.

CALVIN, J. 1986 [1535]. A tous amateurs de Jésus-Christ et de son Évangile, Salut. (In Backus, I. \& Chimelli, C., éditeur, "La vraie piété": Divers traités de Jean Calvin et Confession de foi de Guillaume Farel. Genève : Labor et Fides. [Histoire et Société, 12.] p. 17-38.)

CALVIN, J. 1994. Vorrede zur Olivetanbibel. (In Busch, E., Heron, A., Link, C., Opitz, P., Saxer, E. \& Scholl, H., Hrsg. [Französischer Text mit deutscher Übersetzung, übersetzt und annotiert von E. Saxer.] Calvin-Studienausgabe, Band 1: Reformatorische Anfänge, 1533-1541, Teilband 1/1. Neukirchen-Vluyn : Neukirchener. p. 27-57.)

$\mathrm{CO}[=$ Calvini Opera] see CALVIN, J. 1863-1900.

GANOCZY, A. 1988. The young Calvin. Translated from the French (Le jeune Calvin: Genèse et évolution de sa vocation réformatrice, 1966) by D. Foxgrover and W. Provo. Edinburgh : Clark.

LOCHER, G.W. 1967. Calvin spricht zu den Juden. Theologische Zeitschrift, 23(3): 180-196. 
LUTHER, M. 1966 [1520]. De captivitate Babylonica ecclesiae praeludium. Graz : Akademische Druck- und Verlagsanstalt. (Unveränderter Abdruck der bei Hermann Böhlaus Nachfolger, Weimar, erschienenen Ausgabe von 1888.) p. 484-573.

NEUSER, W.H. 1977. Die reformatorische Wende bei Zwingli. Neukirchen : Neukirchener.

PETER, R. \& GILMONT, J.-F. 1991. Bibliotheca Calviniana. Les œuvres de Jean Calvin publiées au xvie siècle, I. Écrits théologiques, littéraires et juridiques 15321554. Genève : Libraire Droz. (Travaux d'Humanisme et Renaissance, CCLV.)

QUACK, J. 1975. Evangelische Bibelvorreden von der Reformation bis zur Aufklärung. Gütersloh : Gütersloher Verlagshaus G. Moehn. (Quellen und Forschungen zur Reformationsgeschichte, herausgegeben vom Verein für Reformationsgeschichte, Band XLIII.)

RAEDER, S. 1980. Bibelwerke. (In Krause, G., Hrsg. Theologische Realenzyklopädie, Bd. VI. Berlin : De Gruyter. p. 311-316.)

SHIMURA, M. 1994. La crise de l'Evangélisme français, 1525 ou l'Evangélisme radical. (In Neuser, W.H., Hrsg. Calvinus Sacrae Scripturae Professor - Calvin as Confessor of Holy Scripture: Die Referate des Internationalen Kongresses für Calvinforschung vom 20. bis 23. August 1990 in Grand Rapids. Grand Rapids, Mich. : Eerdmans. p. 240-244.)

STAUFFER, R. 1978. Dieu, la création et la Providence la prédication de Calvin. Frankfurt am Main : Lang.

STRASSER, O.E. 1957. Calvin, Johannes (1509-1564). (In Galling, K., Hrsg. Die Religion in Geschichte und Gegenwart: Handwörterbuch für Theologie und Religionswissenschaft, Bd. I. Dritte, völlig neu bearbeitete Auflage. Tübingen : Mohr (Paul Siebeck). Column 1588-1593.)

V.F.C. a nostre allié et confederé le peuple et l'alliance de Sinai ... 1970 [1535]. [Preface in the Bible of Olivétan, 1535.] (Facsimile in Droz, E., ed., Chemins de l'hérésie: Textes et documents, Tome premier. Genève: Slatkine Reprints. [The print of the facsimile is between p. 110 and 111.])

WA [ = Weimarer Ausgabe] see LUTHER, M.

WOOTTON, R.W.F. 1980. Bibelübersetzungen, V. (In Krause, G., Hrsg. Theologische Realenzyklopädie, Bd. VI. Berlin : De Gruyter. p. 299-311.)

\section{Key concepts:}

Calvin; his theology

law; its fulfilment

natural theology

Olivétan Bible

\section{Kernbegrippe:}

Calvyn; sy teologie

natuurlike teologie

Olivétan: Bybel

wetsvervulling 


\section{Appendix to "the first outline of Calvin's theology"1. Calvin's preface to the New Testament in the Bible of Olivétan (1535)}

To all those who love Christ and his Gospel, greetings.

5 [How our Lord Jesus Christ is the End of the Law = 1543]

\section{Section 1:}

God the Creator2, the most perfect and excellent Maker of all things, who had already shown himself more than admirable in their creation ${ }^{3}$, made man as his masterpiece, to surpass all other creatures. Man is endowed

10 with a singular excellence, for God formed him in his own image and likeness ${ }^{4}$, in such manner that the light of his glory shone brightly in him. Now, what would have enabled man to remain in the state in which he was established, was that, in humility, he should bow himself lowly before the majesty of God, magnifying him with thanksgiving5; not to

15 seek his glory in himself, but knowing that all good things come from above, always to look above and to glorify the one and only God6 to whom belongs the praise.

But the wretched man, wanting to be somebody in himself, began incontinently to forget and misunderstand from whence the good came to

20 him7; and in outrageous ingratitude attempted to exalt himself in pride against his Maker and the Author of all these benefits. For this reason, he went down in ruin and lost all the dignity and superiority of his first creation; he was despoiled and divested of all his glory and alienated from all the gifts which were entrusted to him; to the end that he might

25 be confounded in his pride and to constrain him to learn what he not

1 For the purpose of reference I enclosed as appendix an English translation (referred to as "appendix") in which the sections and lines are numbered. The text is derived from Calvin (1958) and Calvin (1963); the latter is more exact - WHN.

2 Rom. 1:25.

3 Rom. 1:20.

4 Gen. 1:26; cf. Acts 17:28.

5 Rom. 1:21.

6 Rom. 1:21.

7 Acts 14:17. 
voluntarily wanted to hear, namely that he was by himself nothing but vanity, and would never have been anything else except with the assistance of the Lord of strength. 8

\section{Section 2:}

5 Therefore, from that time God also began to hate him and, as he well merited, to disavow him as his work, seeing that his image and likeness was effaced from man and that the gifts of his kindness ${ }^{9}$ were no longer in him. And, as he had sent man forth and ordained to please himself and to take his delight in man, as a father would take pleasure in his well-

10 beloved child; so, on the contrary, he despised and abominated man, in such a way, that all which had been pleasing to him, it now gave him displeasure; everything that in which he had taken delight, angered him; everything that he had contemplated with benign and parental regards, he now took to detest and to look at with regret. In short, the whole man

15 with all that he had, his deeds, his thoughts, his words, his life, wholly displeased God, as though man were a special enemy and adversary of God; so that God repented of having made him.10 After having been cast down into such a confusion, man was fruitful in his cursed seed11, to beget a race like himself; that is, vicious, perverse, corrupt, void, and

20 deprived of all good, rich and abundant in evil12.

\section{Section 3:}

Nevertheless, the lord of mercy, who not only loves but is himself love and charity, being ready in his infinite kindness ${ }^{13}$ to love him who deserved no love, did not entirely expel, consume and ruin men, as their iniquity

25 demanded14; but he sustained and supported them in kindness and patience ${ }^{15}$, giving them time and opportunity to return to $\operatorname{him}^{16}$ and to apply themselves again to that obedience from which they had turned

$\begin{array}{ll}8 & \text { Cf. Rom. 1:20. } \\ 9 & \text { Rom. 2:4. } \\ 10 & \text { Gen. 6:6. } \\ 11 & \text { Gen. 3:17 } \\ 12 & \text { Gen. 6:1-5. } \\ 13 & \text { Rom. 2:4. } \\ 14 & \text { Cf. Gen. 8:21. } \\ 15 & \text { Rom. 2:4. } \\ 16 & \text { Cf. Acts 17:30. }\end{array}$


aside. And even though he disguised himself and kept silent ${ }^{17}$, as though he wished to hide himself from them, leaving them to go after their desires and the yearnings of their lusts ${ }^{18}$, without law ${ }^{19}$, without order, without any correction of his word, he nevertheless has given them enough indications,

5 which ought to incite them to seek him, to reach out for him and to find him $^{20}$, in order to know him and to hounor him as is his due ${ }^{21 .}$

For he has raised everywhere, in all places and in all things, his ensigns and emblems, under escutcheons of so clear intelligence that no one can pretend ignorance in not knowing such a sovereign lord, who has so amply

10 exalted his magnificence; who has, in all parts of the world, in heaven and on earth, written and, as it were, engraved the glory of his power, goodness, wisdom, and eternity. Saint Paul has therefore said quite rightly that the lord has never left himself without a witness22; even among those to whom he has not sent any knowledge of his word. It is evident that all

15 creatures, from those in the firmament to those which are in the centre of the earth ${ }^{23}$, are able to act as witnesses and messengers of his glory to all men; to draw them to seek God, and after having found him ${ }^{24}$, to do him that homage and service befitting the dignity of a lord so good, so powerful, so wise, and who is eternal; yea, each (creature) do help, each in its place,

20 in this quest 25 . For the little birds that sing, sing to God26; the beasts shout aloud to him 27 ; the elements tremble at the presence of him $^{28}$, the mountains echo him, the rivers and fountains cast their tender glances at him $^{29}$, and the herbs and flowers laugh [rejoice] before him. Truly there is no need to go far to seek him, because every one can find him in him-

Cf. Rom. 1:20; Acts 14:16.

18 Rom. 1:24.

19 Rom. 2:12 ff.

20 Acts 17:27.

21 Rom. 1:21 and 28.

22 Acts 14:17.

23 Cf. Rom. 1:20, since the creation of the world.

24 Acts 17:17.

25 Cf. Ps. 19:4, Vulg.

26 Cf. Ps. 104:12.

27 Cf. Ps. 147:9.

28 Ps. 114,7.

29 Ps. 98:7-8. 
self 30 , inasmuch as we are all sustained and preserved by his power which is in $u s^{31}$.

\section{Section 4:}

In order to manifest ${ }^{32}$ still more largely his infinite goodness and kindness

5 toward men, he was not content to instruct them by ensigns as we have just described; but he made his voice to be heard in a special manner by a certain people, whom he elected, by his good will and free grace, from among all the nations of the earth. These were the children of Israel, to whom he showed clearly by his word what he is, and declared to them by

10 his marvelous works what he can do. For, he drew them away from subjection to Pharaoh the king of Egypt, under whom they were held down and oppressed, to deliver them and set them at liberty. He accompanied them night and day in their flight, as one fugitive in their midst. He fed them in the desert. He made them to possess the promised land. He gave

15 victories and triumphs to their hands. And as though he were nothing to the other nations, he wanted expressly to be called the God of Israel, and to have Israel called his people33, on condition that they would recognise no other lord and receive no other god 34 . And this covenant was confirmed and handed down by authentic instruments of testament and testimony

20 given by himself.

\section{Section 5:}

Nevertheless, these people, exhibiting their cursed origin, and showing themselves true heirs of the wickedness of their father Adam. They were unmoved by all these kinds of remonstrance [of God], and did not listen to

25 the teaching by which God admonished them. The works of creation that had the glory and magnificence of God stamped upon them were of no help to the gentiles to bring them to glorify him, to whom they testified. And the law and the prophets did not have the power to lead the Jews in the right way. All have been blind $\mathbf{3 5}$ to the light, deaf to admonitions, and

30 hardened against the commandments.

Acts 17:27.

Acts 17:28.

32 Rom. 1:19.

Exod. 5:1.

Exod. 20:3.

Rom. 1:21b. 
It is true enough that the gentiles, astonished and convinced by so many goods and benefits which they beheld around them, have been forced to recognise the hidden 36 benefactor from whom came so much good[ness] ${ }^{37}$. But instead of giving the true God38 the glory which they owed

5 him, they invented for themselves a god after their own desire, and according to that which their foolish fantasy 39 , in its vanity and deceit has dreamt of; and not one god only, but as many as their temerity and conceit enabled them to pretend and to set up; so that there was not a people or region which did not make to itself new gods as seemed good to them.

10 From thence idolatry began its reign, that perfidious panderer, to turn men away from God, and to make to themselves lots of idols 40 to which they themselves had given forms, name, and being.

As for the Jews, even though they received and accepted the messages and commandments which their Lord sent them by his servants, they have

15 nonetheless immediately falsified the faith before him, turned carelessly away from him, violated and despised his law, hated it, and resisted walking in its ways. They have become strangers to the house of God and run as dissolute men after other gods, committing idolatry after the manner of the Gentiles, contrary to the will of God.

20 Wherefore, if God were to approach his people, whether Jew or Gentile, a new covenant was needed: one which would be certain, sure, and inviolable. And to establish and confirm it, it was necessary to have a Mediator, who would intercede and come between the two parties, to make concord between them; for without this, man would always have had

25 to live under the ire and indignation of God, and would have had no means of relief from the curse, misery, and confusion into which he was snared and had fallen. And it was our Lord and Saviour Jesus Christ, the true and only eternal Son of God, who had to be sent and given to mankind by the Father, to restore a world otherwise wasted, destroyed, and desolate.

\section{Section 6:}

Also from the very beginning, the world was not without the hope of recovering the loss suffered in Adam. For even Adam, in spite of his incontinence after his ruin, was given the promise that the seed of the

Rom. 1:20. 
woman would crush the head of the serpent 41 ; which is to say that Jesus Christ born of a virgin would strike down and destroy the power of Satan.

After that, this promise was renewed more fully to Abraham, when God told him that all the nations of the earth would be blessed in his seed $\mathbf{4 2}$.

5 This meant that from his seed would come Jesus Christ according to the flesh, by whose blessing all men of every land would be sanctified. And the same promise was renewed to Isaac, in the same form and in the same words 43 ; and after that it was announced often, repeated and confirmed by the testimony of the various prophets, so as to state plainly, and most

10 reliably, of whom Christ was to be born, at what time, in what place; what afflictions and death he was to suffer, and with what glory he was to rise from the dead; what was to be his Kingdom, and to what salvation he was to bring his people.

Firstly [regarding to whom he was born], it is foretold for us in Isaiah, how

15 he was to be born of a virgin: "Behold, a virgin shall conceive and shall bear a son, and you shall call his name Immanuel"44. The time is described for us in Moses, when good Jacob says, "The sceptre shall not be taken from the line of Judah, nor the government from his hand, until the coming of the One who is to be sent; and the same is the expectation

20 of the nations" 45 . And this was verified when Jesus Christ came into the world; for the Romans, after having divested the Jews of all government and rule, had, thirty-seven years before [the coming of Christ] ordained Herod king over them, whose father was Antipater the Edomite and his mother an Arabian; he was therefore a foreigner. It had happened

25 sometimes before that the Jews had been without a king; but they had never before been left as they were now without counselors, rulers, and lawgivers. Another numbering [of the time of Christ's coming] is given in Daniel, by the reckoning of the seventy weeks 46 . The place of his birth was given us clearly by Micah, who said, "And thou Bethlehem Ephrata, thou

30 are the least among the thousands of Judah; but from thee shall come for me the One who shall reign over Israel; and his coming shall be for all the days of eternity" $\mathbf{4 7}$. As for the afflictions he was to bear for our deliverance

Gen. 3:15.

42 Gen. 12:3.

43 Gen. 26:24.

44 Is. $7: 14$.

45 Gen. 49:10.

46 Dan. 9:24.

47 Mi. 5:1, Vulg. 
and the death he was to suffer for our redemption, Isaiah48 and Zechariah 49 have spoken of those matters fully and with certainty. The glory of his resurrection 50 and the nature of his Kingdom ${ }^{51}$, and the grace of the salvation 52 he was to bring to his people - these things were fully

5 treated by Isaiah, Jeremiah, and Zechariah.

\section{Section 7:}

Such promises, declared and testified to by these holy men who were filled with the Spirit of God, have been the comfort and consolation of the children and elect of God, who have nourished, supported, and sustained

10 their hope in these promises, waiting upon the will of the Lord to show forth what he had promised. Many kings and prophets among them have desired greatly to see its accomplishment, never ceasing all the while to understand, in their hearts and spirits by faith, the things they could not see with their eyes. And, God has confirmed his people in every possible way

15 during their long waiting for the great Messiah, by providing them with his written law, containing numerous ceremonies, purifications, and sacrifices.

But they were the figures and shadows of the great blessings to come with Christ, who alone was the embodiment and truth of them. For the law was incapable of bringing anyone to perfection; it only pointed out Christ, and

20 like a teacher spoke of and led to him53, who was, as was said by Saint Paul54, the end and fulfilment of the law. Similarly, many times and in various seasons, God sent his people kings, princes, and captains, to deliver them from the power of their enemies, to govern them in peace, to recover their losses, to give them flourishing reigns, and by great prowess

25 to make them renowned among all the other peoples. He did all this to give them a foretaste of the great miracles they were to receive from this great Messiah, who was to be endowed with all the power and might of the Kingdom of God.

But when the fullness of time had come and the period foreordained by

30 God was ended, this great Messiah, so promised and so awaited, came; he was perfect, and accomplished all that was necessary to redeem us

Is. $53: 2 \mathrm{ff}$.

49 Zech. 12:10.

50 Is. $26: 19$.

$51 \quad$ Is. $25: 8 ; 35: 1 \& 7 ; 62: 3$; Jer. 3:17.

52 Zech. 9:9.

53 Gal. 3:24.

54 Rom. 10:4. 
and save us55. He was given not only to the Israelites, but to all men, of every people and every land, to the end that by him human nature might be reconciled to God. This is what is stated plainly in the next book (the New Testament), and set forth there openly. This book we have translated

5 as faithfully as we were able according to the truth and the style of the Greek language, to enable all Christians, men and women, who know the French language, to understand and acknowledge the law they ought to obey and the faith they ought to follow.

\section{Section 8:}

10 [The sum of all that is necessary to look for in Scripture $=1543$ ]

And this book is called the New Testament in relation to the Old, which, in so far as it had to be succeeded by and related to the New, and was weak and imperfect in itself, was abolished and abrogated. It is the new and the eternal testament ${ }^{56}$ (covenant), which will never grow old and fail, because

15 Jesus Christ is its Mediator. He has ratified and confirmed it by his death, by which he has accomplished full and complete remission of all sins (prevarications) which remained under the first testament (covenant)57.

Scripture also calls it gospel, that is, new and joyful news, because in it is declared that Christ, the sole true and eternal Son of the living God58, was

20 made man, to make us children of God his Father, by adoption59. Thus he is our only Saviour, to whom we owe our redemption, peace, righteousness, sanctification, salvation, and life; who died for our sins and rose again for our justification; who ascended to heaven for our entry there and took possession of it for us and [it is] our home; to be always our helper

25 before his Father; as our advocate and perpetually doing sacrifice for us, sits at the Father's right hand as King, made Lord and Master over all, so that he may restore all that is in heaven and on earth; an act which all the angels, patriarchs, prophets, apostles did not know how to do and were unable to do, because they had not been ordained to that end by God.

\section{Section 9:}

As the Messiah had been promised so often in the Old Testament by the many testimonies of the prophets, so also Jesus Christ was by sure and

Gal. 4:4.

56 Hebr. 9:15.

57 Hebr. 9:15.

58 Matth. 16:16.

59 Gal. 4:5. 
certain testimonies declared to be the One, and none other, who was to come and was to be waited for. For the Lord God has made us so completely certain in this matter, by his Word and his Spirit, by his angels, prophets, apostles, and even by all his creatures, that nobody is

5 in a position to contradict it without resisting and rebelling against God's power. In the first place, the eternal God has testified to us by his voice itself (which is without doubt irrevocable truth), saying, Behold my well beloved Son, in whom I am well pleased; hear him60. And as Saint John says, the Holy Spirit himself is our great witness in our hearts61. The 10 angel Gabriel, sent to the Virgin Mary, said to her: Behold, you shall conceive in your womb, and shall bear a Son, and shall call his name Jesus; for he shall be great and shall be called the Son of the Most High. And the Lord God shall give him the throne (le siege) of his father David, and he shall reign forever in the house of Jacob; and there shall be no

15 end to his Kingdom62. This same message was given in substance to Joseph; and later also to the shepherds, who were told that the Saviour was born, who was Christ the Lord63. And this message was not only brought by an angel, but was confirmed by a multitude of angels, who all together glorified the Lord and announced peace upon earth64. Simeon

20 then just confessed it nobly in the spirit of prophecy: and taking the little child in his arms, he said: Now, o Lord, let thy servant depart in peace according to thy word. For my eyes have seen thy salvation, which thou hast prepared in the presence of all peoples65. John the Baptist also spoke of him as was fitting, when he saw him coming to the river of

25 Jordan, and said, Behold the lamb of God; behold him who takes away the sins of the world66. Peter and all the apostles have confessed, testified, preached all the things which belong to salvation, of which the prophets had foretold that they would be accomplished in Christ the true Son of God. And those whom the Lord has ordained to be witnesses

30 down to our own age have amply demonstrated the same by their writings, as their readers can see well enough.

All these witnesses come together into a unity so well, and they are of one accord among themselves so fully, that it is easy to recognise in such

$\begin{array}{ll}60 & \text { Matth. 3:17; 17:5. } \\ 61 & \text { 1 John 5:6. } \\ 62 & \text { Luke 1:31 ff. } \\ 63 & \text { Luke 2:10 ff. } \\ 64 & \text { Luke 2:13 ff. } \\ 65 & \text { Luke 2:25 ff. } \\ 66 & \text { John 1:29. }\end{array}$


agreement most certain truth. For there could not be such harmony in lies. Besides, it is not only the Father, the Son, the Holy Spirit, the angels, the prophets and apostles that bear witness to Jesus Christ; his own wonderful works show forth his most excellent power. The sick, the lame, the blind,

5 the deaf, the mute, the paralytic, lepers, lunatics, demoniacs, and even the dead raised by him have carried the emblems of his power. By his power, he has given life; in his name, the works he has had given him to do were sufficient witnesses to him67. Besides, even the wicked and the enemies of his glory were constrained by the very force of truth to confess him and to

10 acknowledge something [of his glory]: for instance, Caiaphas68, Pilate, and his wife69. I do not care to bring up the witness of the devils and unclean spirits, seeing that Jesus Christ rejected them 70 .

In short, all the elements and all the creatures have given Jesus Christ the glory. At his command, the winds ceased, the raging sea subsided 71 , the

15 fish brought two drachmas in his belly 72 , the stones (to render him witness) were broken to pieces, the veil of the Temple was torn in the middle, the sun was darkened, the graves were opened, the many bodies were restored to life 73 . There has been nothing in heaven or on earth which has not witnessed that Jesus Christ is God, Lord and Master, and the great

20 Ambassador of the Father sent here below to accomplish the salvation of mankind.

All these things were announced, manifested, written, and signed in this Testament, by which Jesus Christ has made us his heirs in the Kingdom of God his Father, and declares to us his will (like a testator to his heirs) that it 25 [his Testament] be put into execution.

Now we are called to this inheritance without respect for persons ${ }^{74}$; male and female, small and great, servant or lord, master or disciple, cleric or layman, Hebrew or Greek, French or Latin speaking. No one is rejected from it; whoever with a sure confidence receives him who was sent for him,

John 5:36; 10:25.

68 John 11:49.

69 Matth. 27:19.

70 Mark 1:25.

71 Mark 8:26 par.

72 Matth. 17:24.

73 Matth. 27:51 ff.

74 Rom. 2:11. 
embraces what is presented to him, and in short acknowledges Jesus Christ for what he is and as he is given by the Father.

\section{Section 10:}

And now shall we all who bear the name of Christians, male or female,

5 shall we permit ourselves to dishonour, to conceal, and to corrupt this Testament, which so rightly belongs to us, without which we could not pretend any right to the Kingdom of God, without which we should be ignorant of the great blessings and promises which Jesus Christ has given us, of the glory and beatitude he has prepared for us? We do not know

10 what God has commanded or forbidden us; we cannot tell good from evil, light from darkness, the commandments of God from the ordinances (constitutions) of men. Without the gospel everything is useless and vain; without the gospel we are not Christians; without the gospel all wealth is poverty, all wisdom folly before God; strength is weakness, and all the

15 justice of man is under the condemnation of God.

But by the knowledge of the gospel we are made children of God75, brothers of Jesus Christ 76 , fellow townsmen with the saints 77 , citizens of the Kingdom of Heaven78, heirs of God with Jesus Christ ${ }^{79}$, by whom the poor are made rich, the weak strong, the fools wise, the sinners justified,

20 the desolate comforted, the doubting sure, and slaves free. The gospel is the Word of life and truth. It is the power of God for the salvation of all believers 80 ; and the key to the knowledge of God, which opens the door of the Kingdom of Heaven to the faithful by releasing them from sins, and closes it to the unbelievers, binding them in their sins 81 . Blessed are all

25 they who hear the gospel and keep it;82 for in this way they show that they are children of God. Miserable are those who will not hear it and follow it; because they are children of the devil.

Christians, men and women, hear this and learn. For surely the ignorant man shall perish in his ignorance, and the blind who follows another blind

Gal. 4:6.

76 Cf. Rom. 8:29.

77 Eph. 2:19.

78 Philip. 3:20.

79 Rom. 8:17.

80 Rom. 1:16.

81 Matth. 18:18.

82 Luke 11:28. 
man will fall into the ditch with him83. There is but one way to life and salvation, and that is faith and certainty in the promises of God which cannot be had without the gospel; for by hearing it and knowing it living faith is provided, together with sure hope, and perfect love for God and a

5 lively love toward our neighbour84. Where then is your hope, if you contemn and scorn to hear, see, read, and retain this holy gospel? Those who have their affections fixed upon this world chase with every means whatever they think will bring them happiness, without sparing labour, body, life, or reputation. And all this is done in the service of this wretched

10 body, which has a life so vain, miserable, and uncertain. When it is a question of life immortal and incorruptible, of beatitude eternal and immeasurable, of all the treasures of Paradise, shall we not endeavour to pursue them? Those who give themselves to the mechanical arts, however low and mean these may be, expend pain and labour to learn and know

15 them; and those who aspire to a reputation of greatest excellence torment their minds day and night, to understand something of the human sciences, which are nothing but wind and smoke85. Should we not then much more be employed and diligent in the study of this divine wisdom, which passes beyond the whole world and penetrates as far as the mys-

20 teries of God, which it has pleased him to make, known by his holy Word!

\section{Section 11:}

What then shall estrange and alienate us from this holy gospel? Shall injuries, curses, disgrace, and want of worldly honour?86 But, we know well that Jesus Christ has travelled the same road which we have to follow, if

25 we would be his disciples; that we must not refuse to be despised, mocked, humiliated, and rejected before men. For it is thus that we shall be honored, prized, glorified, and exalted in God's judgment. Will there be banishments, proscriptions, privation from goods and riches? But we know that if we shall be banished from one country, the whole earth is the

30 Lord's 87 , and if we be thrown out of the earth itself, nonetheless we shall not be outside of his Kingdom. [We know] that when we are despoiled and impoverished, we have a Father who is rich enough to nourish us; even that Jesus Christ was made poor, so that we might follow him in his poverty. Will there be afflictions, prisons, tortures, torments? But we know

Luke 6:39.

84 Matth. 22:37-39.

85 Ecc. 1:17.

Cf. Rom. 8:35.

Ps. 24:1. 
by the example of Jesus Christ that this is the way to arrive at glory. Finally, will there be death? But death does not do away with a life that is worth having.

In short, if we have Jesus Christ with us, we shall come upon nothing so 5 accursed that he will not turn it into a blessing; nothing so execrable that it shall not be made holy; nothing so evil that it shall not turn into our good88. Let us not lose our comfort when we see all earthly powers and forces against us; for the promise cannot fail, that the Lord on high will hold in mockery all the assemblings and efforts of men who would conspire

10 against him89. Let us not be desolate, as though all hope were lost, when we see true servants of God die and perish before our eyes. For it was said truly by Tertullian, and so it has been approved and shall be until the consummation of the age, that the blood of the martyrs is the seed of the church 90 .

15 And we have a still greater and a more sure consolation, when we turn our eyes away from this whole world and set aside all that we can see before us, to wait with patience for the great judgment of God, by which in one moment all the machinations of men against him shall be struck down, brought to nought, and overturned. This shall be when the Kingdom of

20 God, which we now see in hope, shall become manifest; when Jesus Christ shall appear in majesty with his angels. It shall then be that the good and the evil shall be present before the judgment seat of this great King. Those who have remained firm in this testament, who have followed and kept the will of this good Father, shall be at his right hand as his true

25 children, and shall be blessed with the fulfilment of their faith, which shall be eternal salvation. And since they were not ashamed to own and confess Jesus Christ, when he was despised and condemned before men, they shall also share in his glory, and shall be crowned with him in eternity. But the perverse, rebellious, and condemned, who have despised and rejected

30 this holy gospel, and similarly those who for the sake of holding on to their honour, riches, and high estate have been unwilling to be humbled and made low with Jesus Christ; who for fear of men have cast aside the fear of God and like bastard [sons] disobeyed this Father - these shall be on

Rom. 8:28.

89 Ps. 2:4.

90 Tertullian, Apologeticum 21,25; CC 1,127: Discipuli vero ... Romae postremo per Neronis saevitiam sanguinem Christianorum seminnaverunt. Also ibid. 50,31, CC 1,171 . 
the left hand; they shall be executed and cast out; for the reward of their unfaithfulness, they shall receive eternal death ${ }^{91}$.

Therefore, when you hear that the gospel presents you Jesus Christ in whom all the promises and gifts of God have been accomplished; and

5 when it declares that he was sent by the Father, has descended to the earth and spoken among men perfectly all that concerns our salvation, as it was foretold in the Law and to the Prophets - it ought to be most certain and obvious to you that the treasures of Paradise have been opened to you in the gospel; that the riches of God have been exhibited and eternal

10 life itself revealed. For, this is eternal life; to know one, only true God, and Jesus Christ whom he has sent92, whom he has established as the beginning, the middle, and the end of our salvation. He [Christ] is Isaac, the beloved Son of the Father who was offered as a sacrifice, but nevertheless did not succumb to the power of death93. He is Jacob the

15 watchful shepherd, who has such great care for the sheep which he guards ${ }^{94}$. He is the good and compassionate brother Joseph, who in his glory was not ashamed to acknowledge his brothers, however lowly and abject their condition95. He is the great sacrificer and bishop Melchizedek, who has offered an eternal sacrifice once for all96. He is the sovereign

20 lawgiver Moses, writing his law on the tables of our hearts by his Spirit. He is the faithful captain and guide Joshua, to lead us to the Promised Land. $\mathrm{He}$ is the victorious and noble king David, bringing by his hand all rebellious power to subjection. He is the magnificent and triumphant king Solomon, governing his kingdom in peace and prosperity. He is the strong 25 and powerful Samson, who by his death has overwhelmed all his enemies.

\section{Section 12:}

It follows that every good thing we could think or desire is to be found in this same Jesus Christ alone. For, he humbled himself to exalt us. He made himself a servant, to set us free. He became poor, to enrich us 97 . He was sold, to buy us back; captive, to deliver us; condemned, to absolve us;

93 Gen. 22.

94 Gen. 30.

95 Gen. 45.

96 Hebr. 7:23.

972 Cor. 8:9. 
he was made a curse 98 for our blessing; the oblation of sins for our righteousness; marred that we may be made fair; He died for our life. [This He did] in such a way that by him hardness is softened, wrath appeased, darkness turned into light, fear reassured, despisal despised, debt can-

5 celled, labour lightened, sadness made merry, misfortune made fortunate, difficulty easy, disorder ordered, division united, ignominy ennobled, rebellion subjected, intimidation intimidated, ambush uncovered, assaults assailed, force forced back, combat combatted, war warred against, vengeance avenged, torment tormented, damnation damned, the abyss

10 sunk into the abyss, hell transfixed, death dead, mortality made immortal. In short, mercy has swallowed up all misery, and kindness all misfortune. For all these things which were to be the weapons of the devil in his battle against us, and the sting of death to pierce us, are turned for us into exercises which we can turn to our profit. So we can boast with the

15 apostle, saying, $O$ hell, where is thy victory? O death, where is thy sting?99 And thence it comes that by such a Spirit of Christ promised to the elect, we live no longer, but Christ lives in us ${ }^{100}$; and we are by the same Spirit seated among those who are in heaven, so that for us the world is no more, even while our conversation is in it; but we are content in all things,

20 whether country, place, condition, clothing, meat, and all such things. And we are comforted in tribulation, joyful in sorrow, glorying under vituperation, abounding in poverty, warmed in our nakedness, patient amongst evils, living in death.

Here is all the wisdom which men can understand, and ought to learn in

25 this life; which no angel101 or man, dead or living, may add to or take away from 102. This is where we ought to stop and put a limit to our understanding, mixing nothing of our own with it and refusing any doctrine whatever which might be added to it. For anyone who undertakes to teach one other syllable beyond what is taught us in it, ought to be accursed

30 before God and his church.

Gal. 3:13.

991 Cor. 15:55.

100 Gal. 2:20

101 Gal. 1:8.

102 Deut. 4:2. 


\section{Section 13:}

And you kings, princes, and Christian lords, who are ordained of God to punish the wicked and to uphold the good in peace103 according to the Word of God - to you it belongs to have this sacred doctrine, so useful and 5 needful104, published, taught, and understood in all your lands, realms, and lordly domains, to the end that God may be magnified by you, and his gospel exalted; because by right it is his due that all kings and kingdoms obey him in all humility and serve his glory.

\section{Section 14:}

10 O you who call yourselves bishops and pastors of the poor people, see to it that the sheep of Jesus Christ are not deprived of their proper pasture; and that it is not prohibited and forbidden to any Christian to be free to read, discuss and interpret this holy gospel in his own language, seeing that such is the will of God, and Jesus Christ commands it 105; for it is for

15 this cause that he has sent his apostles and servants throughout the whole world; giving them the power to speak in all tongues, so that they may in every language preach to every creature106; and he has made them debtors to the Greeks and the barbarians, to the wise and the simple107, in order that none might be excluded from their teaching. Surely, if you are

20 truly their vicars, successors, and imitators, it is your office to do the same, watching over the flock108 and seeking every possible means to have

103 Rom. 13:3 ff.

1042 Tim. 3:16.

105 Matth. 28:19 ff.

106 Acts 2:4 and 8.

107 Rom. 1:14.

108 Acts 20:28. 
everyone instructed in the faith of Jesus Christ, by the pure Word of God. Otherwise, the sentence is already proclaimed and put down in writing, that God will demand their souls at your hands 109 .

It is the will of the Lord of lights by his Holy Spirit, by means of this holy and 5 saving gospel, to teach the ignorant, to strengthen the feeble, to illumine the blind, and to make his truth to reign among all peoples and nations, to the end that the whole world may know but one God and one Saviour, Jesus Christ; one faith, and one gospel. So be it. 